\title{
Protocol
}

\section{Analysis of Pre-mRNA Splicing Using HeLa Cell Nuclear Extracts}

\author{
Timothy W. Nilsen
}

This protocol is used to determine the splicing behavior of pre-mRNAs in cell extracts that are capable of carrying out splicing (e.g., nuclear extracts from HeLa cells). ${ }^{32} \mathrm{P}$-labeled RNA is incubated under splicing conditions for various times, and the resulting products are analyzed on denaturing polyacrylamide gels.

\section{MATERIALS}

It is essential that you consult the appropriate Material Safety Data Sheets and your institution's Environmental Health and Safety Office for proper handling of equipment and hazardous material used in this protocol.

RECIPES: Please see the end of this article for recipes indicated by $<R>$. Additional recipes can be found online at http://cshprotocols.cshlp.org/site/recipes.

Reagents

Denaturing polyacrylamide gel reagents

EDTA (2 mm, pH 8.0)

Ethanol $(100 \%)$

GlycoBlue $(10 \mu \mathrm{g} / \mathrm{mL})$

$\mathrm{NaOAc}(3 \mathrm{~m}, \mathrm{pH} 5.2)$

Phenol:chloroform:isoamyl alcohol (PCA; 25:24:1, w/v)

Proteinase K solution ( $10 \mathrm{mg} / \mathrm{mL}$ )

Radiolabeled RNA markers

RNase inhibitor (RNasin; 40 units/ $\mu \mathrm{L}$ )

RNA (capped and labeled with ${ }^{32} \mathrm{P}[\sim 15,000-20,000 \mathrm{cpm} / \mathrm{ng}]$ )

RNA gel-loading buffer $(1.5 \times)<\mathrm{R}>$

RNA splicing substrate (known to be efficiently spliced in HeLa nuclear extract)

SDS solubilization buffer $(1 \times)<\mathrm{R}>$

Splicing extract (e.g., HeLa cell nuclear extract)

Guidelines for the preparation of extracts are described in Preparation of Nuclear Extracts from HeLa Cells (Nilsen 2013). When harvesting HeLa cells, be careful to remove all the serum (which contains RNases) before the cells are disrupted. Use at least two large-volume washes before pooling the cells for homogenization.

Adapted from RNA: A Laboratory Manual, by Donald C. Rio, Manuel Ares Jr, Gregory J. Hannon, and Timothy W. Nilsen. CSHL Press, Cold Spring Harbor, NY, USA, 2011.

(C) 2013 Cold Spring Harbor Laboratory Press

Cite this article as Cold Spring Harb Protoc; 2013; doi:10.1101/pdb.prot075184 
Splicing master mix $(4 \times)<\mathrm{R}>$

TBE electrophoresis buffer $(10 \times)<\mathrm{R}>$

Equipment

Dry ice

Electrophoresis equipment (including vertical gel, comb spacers, and high-voltage power supply)

Gel dryer

Heat block (set at $95^{\circ} \mathrm{C}$ )

Ice

Microcentrifuge

Microcentrifuge tubes (1.5-mL)

Phosphorimager equipment or X-ray film and intensifying screen

Vortex mixer

Water bath (set at $\left.30^{\circ} \mathrm{C}\right)$

1. Prepare a denaturing polyacrylamide gel.

2. Set up the splicing reactions.

i. Add the following to a $1.5-\mathrm{mL}$ microcentrifuge tube:

$\begin{array}{lr}\text { Splicing extract } & 5 \mu \mathrm{L} \\ \text { RNasin (40 units/ } \mu \mathrm{L}) & 1 \mu \mathrm{L} \\ { }^{32} \text { P-Labeled RNA }(\sim 15-20,000 \mathrm{cpm} / \mathrm{ng}) & 1 \mu \mathrm{L} \\ \text { Splicing master mix }(4 \times) \text { (make fresh for each } & 2.5 \mu \mathrm{L}\end{array}$
experiment)

ii. Mix briefly by vortexing and/or flicking the tube.

iii. Incubate for the desired time $(10-90 \mathrm{~min})$ at $30^{\circ} \mathrm{C}$.

3. Process the splicing reactions for polyacrylamide gel electrophoresis.

i. Add the following to the reaction mixture from Step 2.iii:

$$
\begin{array}{lr}
\text { SDS solubilization buffer } & 200 \mu \mathrm{L} \\
\text { Proteinase } \mathrm{K}(10 \mathrm{mg} / \mathrm{mL}) & 5 \mu \mathrm{L}
\end{array}
$$

ii. Incubate for $15 \mathrm{~min}$ at $42^{\circ} \mathrm{C}$.

iii. Add $0.3 \mathrm{~m} \mathrm{NaOAc}$. Perform a PCA extraction and precipitate the RNA with ethanol containing $20 \mu \mathrm{g}$ of GlycoBlue.

GlycoBlue acts as a coprecipitant to facilitate recovery of RNA and increase the visibility of the precipitate.

iv. Resuspend the RNA in $10 \mu \mathrm{L}$ of 2 mM EDTA. Remove $2.5 \mu \mathrm{L}$ aliquots for electrophoresis and add $5 \mu \mathrm{L}$ of RNA-loading buffer to each sample.

4. Run a denaturing polyacrylamide gel.

i. Set up the gel in the gel box, add running buffer (TBE) to the upper and lower reservoirs, and prerun the gel for 15-45 min at $1500 \mathrm{~V}$ and a maximum $45 \mathrm{~mA}$.

Shorter preruns are allowed when the RNA fragments are all above 100 bases in length.

ii. Heat the samples (from Step 3.iv) for $1 \mathrm{~min}$ at $95^{\circ} \mathrm{C}$ and then place on ice. 
T.W. Nilsen
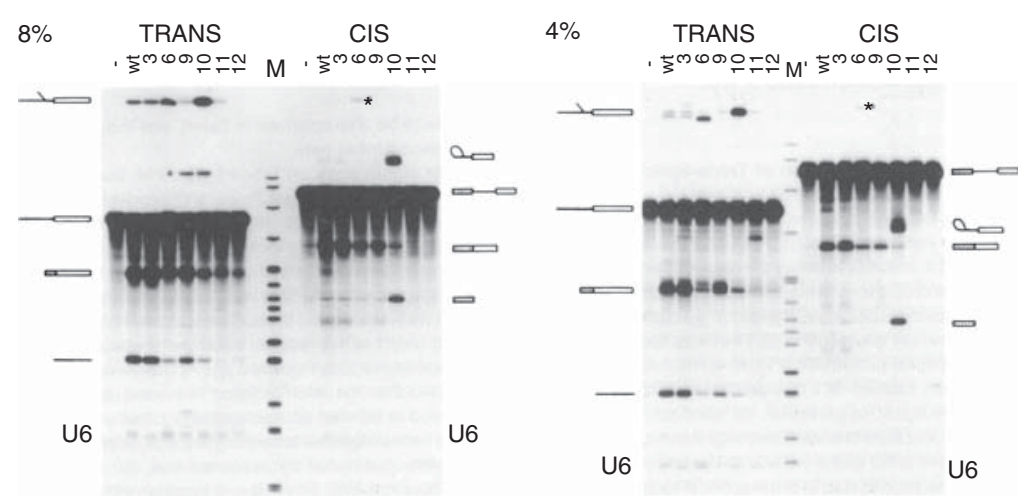

FIGURE 1. An example of a splicing reaction analyzed on high ( $8 \%$ ) and low (4\%) acrylamide gels. Note the striking difference in the mobility of spliced intermediates on the two gels, particularly in the CIS lanes 10. (Reprinted, with permission, from Yu et al. 1993 [C Elsevier]).

iii. Load the samples and run the gel at $1500 \mathrm{~V} / 45 \mathrm{~mA}$ until the desired separation is reached for the expected products and intermediates from the reaction.

iv. Dry the gel and expose on a phosphorimager.

5. Examine and analyze the image pattern.

Some splicing intermediates such as lariat exon 2 and other branched molecules (such as those produced by trans-splicing) will have abnormal mobility on gels. This altered mobility will be more dramatic in higherpercentage gels. It may be necessary to run more than one gel to resolve all of the products and intermediates (Fig. 1). See Troubleshooting.

\section{TROUBLESHOOTING}

Problem (Step 5): Splicing efficiency is low or nonexistent.

Solution: It may be necessary to prepare a new nuclear extract. Before asking any specific question, make sure that the extract is active. We suggest using a splicing substrate that is known to be efficiently spliced in HeLa nuclear extracts (e.g., adenovirus major late or MINX RNA). If the substrate is spliced $\geq 50 \%$ in the extract, proceed with the experiment. If the substrate is spliced poorly or not at all, review the steps in the splicing protocol, and even if everything was performed correctly, a new extract must be prepared. An extract that is "dead" cannot be rescued.

Problem (Step 5): Nuclease activity is a problem (i.e., the substrate is degraded).

Solution: Make sure that the substrate is capped. In addition, ligation of unlabeled pCp to the $3^{\prime}$ end of the substrate can stabilize the substrate caused by the inhibition of $3^{\prime}$ to $5^{\prime}$ exonucleases.

RNA Gel-Loading Buffer (1.5×)

\begin{tabular}{lcr} 
Reagent & $\begin{array}{c}\text { Quantity } \\
\text { (for 10 mL of 1.5×) }\end{array}$ & Final concentration \\
\hline Formamide, ultrapure & $9.5 \mathrm{~mL}$ & $95 \%$ \\
Bromophenol blue $(2.5 \%, \mathrm{w} / \mathrm{v})$ & $100 \mu \mathrm{L}$ & $0.025 \%$ \\
Xylene cyanol FF $(2.5 \%, \mathrm{w} / \mathrm{v})$ & $100 \mu \mathrm{L}$ & $0.025 \%$ \\
EDTA $(0.25 \mathrm{M}, \mathrm{pH} 8.0)$ & $200 \mu \mathrm{L}$ & $5 \mathrm{mM}$
\end{tabular}

Use $5 \mu \mathrm{L}$ for a $2.5-\mu \mathrm{L}$ sample. Purchase a distilled, deionized preparation of formamide and the above loading dyes. Store in small $(1-\mathrm{mL})$ aliquots for up to $1 \mathrm{yr}$ at $-20^{\circ} \mathrm{C}$. This solution is available commercially (Ambion) and is recommended over homemade. 
SDS Solubilization Buffer (1x)

\begin{tabular}{lcc} 
Reagent & $\begin{array}{c}\text { Quantity } \\
\text { (for } 500 \mathrm{~mL} \text { ) }\end{array}$ & Final concentration \\
\hline EDTA (500 mM, pH 8.0) & $1 \mathrm{~mL}$ & $1 \mathrm{~mm}$ \\
SDS (sodium dodecyl sulfate; $10 \%)$ & $25 \mathrm{~mL}$ & $0.5 \%$ \\
Tris-Cl (1 M, pH 7.5) & $10 \mathrm{~mL}$ & $20 \mathrm{~mm}$ \\
$\mathrm{H}_{2} \mathrm{O}, \mathrm{RNase}-$ free & $464 \mathrm{~mL}$ & -
\end{tabular}

Store for up to $1 \mathrm{yr}$ at room temperature.

Splicing Master Mix (4×)

\begin{tabular}{|c|c|c|}
\hline Reagent & $\begin{array}{c}\text { Quantity } \\
\text { (for } 62.2 \mu \mathrm{L} \text { ) }\end{array}$ & $\begin{array}{c}\text { Final concentration } \\
(1 \times \text { in the splicing reaction })\end{array}$ \\
\hline Creatine phosphate $(0.5 \mathrm{M})$ & $10 \mu \mathrm{L}$ & $20 \mathrm{~mm}$ \\
\hline $\operatorname{ATP}(100 \mathrm{~mm})$ & $5 \mu \mathrm{L}$ & $2 \mathrm{~mm}$ \\
\hline $\mathrm{KCl}(3 \mathrm{M})$ & $2.5 \mu \mathrm{L}$ & $30 \mathrm{~mm}^{*}$ \\
\hline $\mathrm{MgCl}_{2}(0.5 \mathrm{M})$ & $2.1 \mu \mathrm{L}$ & $4.2 \mathrm{~mm}$ \\
\hline Dithiothreitol (DTT) (1 M) & $1 \mu \mathrm{L}$ & $4 \mathrm{~mm}$ \\
\hline Tris (1 M, pH 8.0) & $1 \mu \mathrm{L}$ & $16 \mathrm{mM}$ \\
\hline $\begin{array}{l}\text { Aprotinin and leupeptin stock } \\
\text { solution** }\end{array}$ & $1 \mu \mathrm{L}$ & \\
\hline $\begin{array}{l}\text { Polyethyleneglycol (PEG } \\
8000 ; 20 \%, \mathrm{w} / \mathrm{v})^{* * *}\end{array}$ & $37.5 \mu \mathrm{L}$ & $3 \%$ \\
\hline $\mathrm{H}_{2} \mathrm{O}$ & $2.1 \mu \mathrm{L}$ & \\
\hline
\end{tabular}

Prepare fresh and keep on ice.

*The final $\mathrm{KCl}$ concentration in the reaction mixture is usually between 50 and $80 \mathrm{~mm}$ because the splicing extract also contains $\mathrm{KCl}$, which contributes to the final concentration. Adjust according to the concentration in dialysis buffer and the amount of extract used in the reaction.

**Prepare the aprotinin and leupeptin stock solution immediately before use by adding $1 \mu \mathrm{L}$ of a $10-\mathrm{mg} / \mathrm{mL}$ solution of aprotinin and $1 \mu \mathrm{L}$ of a $2-\mathrm{mg} / \mathrm{mL}$ solution of leupeptin to $38 \mu \mathrm{L}$ of $\mathrm{H}_{2} \mathrm{O}$.

***Weigh out 8 g of PEG 8000 (e.g., Carbowax PEG 8000 from Fisher) in a 50-mL conical tube. Add RNase-free $\mathrm{H}_{2} \mathrm{O}$ to the 40 - $\mathrm{mL}$ mark on the tube. Close the lid tightly and heat briefly at $65^{\circ} \mathrm{C}$ to dissolve. Store for $4 \mathrm{mo}$ at room temperature.

TBE Electrophoresis Buffer (10×)

\begin{tabular}{lcc} 
Reagent & Quantity (for 1 L) & Final concentration \\
\hline Tris base & $121.1 \mathrm{~g}$ & $1 \mathrm{M}$ \\
Boric acid & $61.8 \mathrm{~g}$ & $1 \mathrm{M}$ \\
EDTA (disodium salt) & $7.4 \mathrm{~g}$ & $0.02 \mathrm{M}$
\end{tabular}

Prepare with RNase-free $\mathrm{H}_{2} \mathrm{O}$. Dilute $100 \mathrm{~mL}$ to $1 \mathrm{~L}$ to make gel running buffer. Store for up to $6 \mathrm{mo}$ at room temperature.

\section{REFERENCES}

Nilsen TW. 2013. Preparation of nuclear extracts from HeLa cells. Cold Spring Harb Protoc doi: 10.1101/pdb.prot075176.
Yu Y-T, Maroney P, Nilsen TW. 1993. Functional reconstitution of U6 snRNA in nematode cis- and trans-splicing: U6 can serve as both a branch acceptor and a 5' exon. Cell 75: 1049-1059. 


\section{Analysis of Pre-mRNA Splicing Using HeLa Cell Nuclear Extracts}

Timothy W. Nilsen

Cold Spring Harb Protoc; doi: 10.1101/pdb.prot075184

\begin{tabular}{rc}
$\begin{array}{r}\text { Email Alerting } \\
\text { Service }\end{array}$ & Receive free email alerts when new articles cite this article - click here. \\
\hline $\begin{array}{c}\text { Subject } \\
\text { Categories }\end{array}$ & $\begin{array}{c}\text { Browse articles on similar topics from Cold Spring Harbor Protocols. } \\
\text { Molecular Biology, general (1293 articles) } \\
\text { RNA (317 articles) } \\
\text { RNA, general (269 articles) }\end{array}$ \\
\hline
\end{tabular}

